\title{
BELAJAR DENGAN DIALOG (Deep Dialog dan Critical Thiking Sebagai Model Penerapan Pendidikan Karakter)
}

\author{
Jefri Souhuwat \\ jefrisouhuwat89@gmail.com
}

\begin{abstract}
The caregivers of the Church Soya, in carrying out the sagat learning process, were accustomed to using monotonous lecture methods, the use of methods, strategies and learning media rarely seen in the learning process. This study aims to find out what the learning process is with the dialogue on Church Formal Education (PFG) for GPM Soya's. The data of this study were analyzed using qualitative research methods with data collection techniques are observation, interviews and literature and data analysis techniques are data reduction, display data and draw conclusions and verification. By using Deep Dialog and Critical Thiking Theory with dialogue methods in the learning process with results indicators are Silence, community building, concept discovery activities, reflection and evaluation.The results found in this study were that caregivers found it very difficult to use the method of dialogue with students, so the teaching and learning process carried out was very monotonous by using the lecture method. Children's creativity and caregivers are not honed and have no development. In-depth dialogue with children's goals and caregivers are open, honest, respectful of others and independent learning has not occurred in the learning process. These findings are analyzed by means of learning with silence in establishing internal and external dialogue, building a class community for democratic dialogue, finding concepts for independence in dialogue, reflection as an educational and evaluation dialogue as a means of achieving learning with dialogue.
\end{abstract}

Keyword: Church Formal Dialogue and Education (PFG)

\section{Pengantar}

Pendidikan merupakan upaya untuk mendewasakan manusia dalam berbagai segi. Setiap pengalaman yang memiliki efek formatif pada cara orang berpikir, merasa, atau tindakan dapat dianggap pendidikan. Pengertian pendidikan dalam kamus besar Bahasa Indonesia ialah proses pengubahan sikap dan tingkah laku seseorang atau kelompok orang dalam usaha mendewasakan manusia melalui upaya pengajaran dan pelatihan. (Rahmaniyah:2010) Pendidikan umumnya dibagi dalam beberapa tahapan seperti prasekolah, sekolah dasar, sekolah menengah dan kemudian perguruan tinggi, universitas atau magang. Pendidikan dilaksanakan melalui berbagai proses, baik informal, formal maupun nonformal. Terutama pelaksanaan pendidikan di Indonesia, pendidikan dilaksanakan dalam tiga lembaga tersebut.

Namun, praktik pendidikan di Indonesia, dalam kapasitas pendidikan formal, cenderung lebih berorentasi pada pendidikan yang berbasis hard skill (keterampilan teknis) yaitu pendidikan yang lebih bersifat mengembangkan intelligence quotient (IQ), namun kurang mengembangkan kemampuan soft skill yang tertuang dalam emotional intelligence (EQ), dan spiritual intelligence (SQ). Bahkan, pembelajaran di berbagai sekolah bahkan perguruan tinggi lebih menekankan pada perolehan nilai hasil ulangan maupun nilai hasil ujian atau dapat dikatakan berorientasi pada aspek kognitif saja. Banyak kalangan yang memiliki persepsi bahwa peserta didik yang memiliki kompetensi yang baik adalah memiliki nilai hasil ulangan/ ujian yang tinggi, sedangkan mereka yang hasil ulangannya rendah dapat dikatakan tidak memiliki kompetensi yang memadai. Maka tak heran Ujian Nasional (UN) sering dijadikan acuan dalam keberhasilan peserta didik, meskipun belum tentu benar. Seiring perkembangan jaman, pendidikan yang hanya berbasiskan hard skill kini tak relevan lagi. Bahkan, kalau mau belajar dari negara maju. Pendidikan di negara-negara maju tersebut berhasil, misalnya Finlandia, karena menekankan pada pembangunan soft skill. Bahkan keberhasilan penguasaan sains dan teknologi juga merupakan hasil alami dari kuatnya dasar-dasar soft skill. (Haidar Bagir:2014)

Maka, pembelajaran juga harus berbasis pada pengembangan soft skill (interaksi sosial) sebab ini sangat penting dalam pembentukan karakter anak bangsa sehingga mampu bersaing, beretika, bermoral, sopan santun dan berinteraksi dengan masyarakat. Pendidikan soft skill bertumpu pada pembinaan mentalitas agar peserta didik dapat menyesuaikan diri dengan realitas kehidupan. Kesuksesan seseorang tidak ditentukan sematamata oleh pengetahuan dan keterampilan teknis (hard skill) saja, tetapi juga oleh keterampilan mengelola diri dan orang lain (soft skill). 
BELAJAR DENGAN DIALOG (Deep Dialog dan Critical Thiking Sebagai Model Penerapan Pendidikan Karakter)

Pendidikan karakter adalah pendidikan budi pekerti plus, yaitu yang melibatkan aspek pengetahuan ( cognitive), perasaan (feeling), dan tindakan (action). Tanpa ketiga aspek tersebut, pendidikan karakter tidak akan efektif. Pendidikan karakter lebih tepatnya merupakan salah satu sarana soft skill yang dapat diintegrasikan dalam pembelajaran pada setiap mata pelajaran. Materi pembelajaran yang berkaitan dengan norma atau nilai-nilai pada setiap mata pelajaran perlu dikembangkan, dieksplisitkan, dikaitkan dengan konteks kehidupan sehari-hari. Bahkan setiap materi dalam sebuah mata pelajaran perlu diintegrasikan dengan pendidikan karakter. Dengan demikian, pembelajaran nilai-nilai karakter tidak hanya pada tataran kognitif, tetapi menyentuh pada internalisasi, dan pengamalan nyata dalam kehidupan peserta didik sehari-hari di masyarakat. Itulah sebabnya pendidikan karakter menjadi landasan kemajuan setiap anak dalam mengimplementasikan nilai dari setiap pengetahuan yang didapatkan dalam dunia pendidikan.

Pembangunan karakter yang merupakan upaya perwujudan amanat pancasila dan pembukaan UUD 1945 dilatar belakangi oleh realita permasalahan kebangsaan yang berkembang saat ini, seperti: disorientasi dan belum dihayatinya nilai- nilai pancasila; bergesernya nilai etika dalam kehidupan berbangsa dan bernegara; memudarnya kesadaran terhadap nilai-nilai budaya bangsa; ancaman disintregasi bangsa; dan melemahnya kemandirian bangsa. Untuk mendukung perwujudan cita-cita pembangunan karakter sebagaimana diamanatkan pancasila dan pembukaan UUD 1945 serta mengatasi permasalahan kebangsaan saat ini, maka pemerintah menjadikan pembangunan karakter sebagai salah satu program prioritas pembangunan nasional. Semangat itu secara implisit ditegaskan dalam Rencana Pembangunan Jangka Panjang Nasional (RPJPN) tahun 20052025, dimana pendidikan karakter ditempatkan sebagai landasan untuk mewujudkan visi pembangunan nasional, yaitu "Mewujudkan masyarakat berakhlak mulia,bermoral,beretika, berbudaya dan beradab berdasarkan falsafah pancasila.'

Terkait dengan upaya mewujudkan pendidikan karakter sebagaimana yang diamanatkan dalam RPJPN, sesungguhnya hal yang dimaksud itu sudah tertuang dalam fungsi dan tujuan pendidikan nasional, yaitu: "Pendidikan nasional yang berfungsi mengembangkan dan membentuk watak serta heradapan bangsa yang bermartabat dalam rangka mencerdaskan kehidupan bangsa,bertujuan untuk berkembangnya potensi peserta didik agar menjadi manusia yang beriman dan bertaqwa kepada Tuhan Yang Maha Esa, beraklak mulia, sehat, berilmu, cakap, krestif, mandiri, dan menjadi warga negara yang demokratis serta bertanggung jawab. (Kementrianpendidikan nasiona:2011)

Dengan demikian pengembangan pendidikan karakter baik Pendidikan Formal, non formal dan in formal merupakan sebuah rancangan jangka panjang secara nasional terhadap pendidikan dan menjadi gumulan setiap pendidik/pengajar dalam mengembangkan kualitas anak lewat pendidikan karakter tersebut. Namun bukti belum maksimalnya penanaman dan pengembangan pendidikan pendidikan karakter tersebut adalah masih banyaknya kasus-kasus kekerasan yang terjadi di masyarakat, baik pisik maupun psikis, baik dilakukan oleh individu maupun kelompok.

Masih banyaknya kasus-kasus kekerasan yang tejadi di sekolah-sekolah, tawuran antar pelajar, tawuran antar mahasiswa, sampai ada yang menjadi kurban hingga meninggal gara-gara tawuran. Masih banyaknya tindakan -tindakan tercela yang terjadi di masyarakat. Makin maraknya tindak kejahatan, berkembangnya tindakan-tindakan asusila, rusaknya kehidupan generasi muda,maraknya pergaulan bebas, free sex, kasus-kasus aborsi dan sebagainya, rendahnya moralitas bangsa, menunjukkan bahwa kekerasan semakin mengakar dan membudaya di masyarakat . Hal yang demikian ini merupakan sebagian dari bukti nyata bahwa pendidikan karakter masih berupa slogan, kurang diimplemntasikan dengan optimal dalam kehidupan sehari-hari, dan kehidupan bersama baik di dalam keluarga, masyarakat maupun di sekolah-sekolah.

Pendidikan sebagai pusat belajar dan pusat budaya memiliki fungsi yang strategis untuk menanamkan dan mengembangkan karakter kepada generasi penerus masa depan bangsa. Dalam model penerapannya harus memiliki tahapan yang sistematis sehingga benar anak bukan hanya dinilai dari hasil terakhir atau ujian semata.

Tetapi proses pengembangan karakter anak mulai mengalami perubahan dari waktu ke waktu. Itulah sebabnya dalam proses pengimplementasian pengajaran/pembelajaran anak akan diarahkan dalam proses pembelajaran yang sistematis bukan hanya di dunia pendidikan formal semata tetapi dalam pendidikan in formal dan non formal juga dapat diterakpakan pembelajaran yang sistematis 
Jefri Souhuwat

yakni penerapan model pembelajran Deep dialog dan Chritical thiking.

Pendidikan formal Gereja (PFG) khususnya Jemaat GPM Soya dalam hal ini sekolah minggu yang menjadi focus penelitian ini dalam proses belajar dengan dialog kurang diterapkan secara maksimal bagi anak didik. Selama ini pengasuh hanya menjalankan tugas mengajarnya dengan cara mereka sendiri, yakni ceramah yang menjadi muatan utama para pengajar melakukan pengajaran mereka. Dialog dengan anak kurang dilakukan secara mendalam, anak hanya duduk dan lebih banyak mendengar apa yang diajarkan oleh pengasuh.

Hal ini terjadi karena banyak pengasuh yang menganggap bahwa mengajar kepada anak adalah hal yang biasa-biasa saja, karena mereka masih belum diajak dialog. Dinamika perkembangan pembelajaran di kelas kurang dikemas secara baik sehingga tidak muncul proses berdialog yang kreatif dan inovatif demi perkembangan belajar anak didik. Pengasuh kurang memahami bagaimana proses belajar dengan dialog bagi anak sehingga ceramah menjadi suatu hal rutininas.

Dengan demikian pembentukan karakter anak tidak diasah dengan baik sehingga anak dalam proses perkembangannya tidak mampu merespons hal-hal yang menurut dirinya bermanfaat bagi perkembangan karakter dirinya. Tingkat pengambilan keputusan seorang anak akan salah ketika tidak diasah dengan baik dalam proses belajarnya sehingga tingkatan analisa, berfikir kritis, merefleksikan sesuatu serta mengevaluasi dirinya sendiri tidak menjadi landasan yang kuat dalam diri anak sendiri.

\section{Tinajauan Literatur}

\subsection{Model pembelajaran deep dialog dan chritical thiking.}

Model adalah contoh, pola, acuan, ragam, macam, dan sebagainya dari sesuatu yang akan dibuat atau dihasilkan. (KBBI:1995) Dalam konteks pembelajaran, model pembelajaran dapat diartikan sebagai suatu rencana mengajar yang memperlihatkan pola pembelajaran tertentu. (Trianto:2009) Sedangkan model pembelajaran Deep Dialogue dan Critical Thinking adalah model pembelajaran yang mengkonsentrasikan kegiatan pembelajaran untuk mendapatkan pengetahuan dan pengalaman, melaui dialog secara mendalam dan berpikir kritis. (Arhana, Ketut:2007)

Dialog adalah percakapan antara orang-orang dan melalui dialog tersebut, dan masyarakat kelompok atau lebih yang memiliki pandangan berbeda-beda bertukar ide, informasi dan pengalaman. Jadi Deep Dialogue Critical Thinking (dialog mendalam) dapat diartikan bahwa percakapan antara orang-orang harus diwujudkan dalam hubungan yang interpersonal, saling keterbukaan, jujur dan mengandalkan kebaikan. (Suyatno:2009)

Dialog merupakan salah satu model pembelajaran untuk memberi motivasi kepada peserta didik untuk aktif bertanya selama pendidik yang menyuguhkan pertanyaan-pertanyaan dan peserta didik menjawab. Dengan berdialog juga dapat membantu tumbuhnya perhatian peserta didik pada pelajaran serta mengembangkan kemampuannya untuk menggunakan pengetahuan dan pengalaman sehingga pengetahuannya menjadi fungsional.

Diskusi, dialog dan tukar gagasan akan membantu peserta didik mengenali hubunganhubungan baru tentang sesuatu dan membantu mereka memiliki pemahaman yang lebih baik. (Hamdani:2011)

Berpikir dalam Kamus Besar Bahasa Indonesia adalah menggunakan akal budi untuk mempertimbangkan dan memutuskan sesuatu.

Sedangkan Kritis dalam Kamus Besar Bahasa Indonesia adalah tidak lekas percaya, tajam dalam penganalisaan. (KBBI:1995)Menurut Krulick dan Rudnick berpikir kritis adalah berpikir yang melibatkan aktivitas menguji, menghubungkan, mengevaluasi semua aspek sebuah situasi atau masalah, termasuk juga mengumpulkan, mengorganisasikan, mengingat, dan menganalisis informasi.

Pandangan lain datang dari Glazer yang menyatakan bahwa berpikir kritis dalam matematika adalah kemampuan yang melibatkan pengetahuan sebelumnya, penalaran matematis, dan strategi kognitif untuk mengeneralisasi, membuktikan atau mengevaluasi situasi matematis yang dikenal dalam cara yang reflektif. (Zulmaulida, Rahmy:2012)

Dalam pengertian lain seseorang dikatakan berpikir kritis bila menanyakan suatu hal, karena tidak lekas percaya pada keadaan yang baru kemudian mencari informasi dengan tepat. Kemudian informasi tersebut digunakan untuk menyelesaikan masalah dan mengelolahnya secara logis, efisien dan kreatif sehingga dapat membuat kesimpulan yang dapat diterima akal. Selanjutnya informasi tersebut digunakan untuk memecahkan masalah yang dihadapi dengan tepat berdasarkan 
analisis informasi dan pengetahuan yang dimilikinya.(Sumaryono:2010)

Deep Dialog (Dialog Mendalam) dapat diartikan bahwa percakapan antara orang-orang harus di wujudkan dalam hubungan interpersonal, saling keterbukaan, jujur dan mengandalkan kebaikan. Sedangkan Critical Thinking (berpikir kristis) adalah kegiatan berpikir yang dilakukan dengan mengoperasikan potensi intelekstual untuk menganalisis, membuat pertimbangan dan mengambil keputusan secara tepat dan melaksanakannya secara benar. (Swidler. L. Regilion:2000)

Global Dialog Institute dalam Umi Salamah menjelaskan bahwa ciri-ciri pembelajaran menggunakan model Deep Dialog/Critical Thinking yaitu :

- Peserta didik dan guru nampak aktif. Ada proses interaksi yang diangun dalam proses belajar mengajar yang dilaukan sehingga Nampak bahwa Anak dan Guru aktif berdialog.

- Mengiptimalisasikan potensi intelegensi peserta didik. Dibutuhkan proses mencari makna oleh anak sehingga stimulus yang berikan Guru anak dapat dengan mudah mengetahui dan kemudian memberikan respons yang sesuai dengan yang ditanyakan.

- Berfokus pada mental, emosional dan spiritual. Ciri-ciri ini lebih difokuskan pada psikologi anak anak dan Guru sehingga keduanya mampu memahami dirinya secara fisik, mengontrol emosi dalam proses belajar bahkan spiritualitasnya tetap stabil.

- Menggunakan pendekatan dialog mandalam dan berpikir kritis. Ciri-ciri ini yang akan memperkuat metode dialog mendalam dan berfikir kritis. Anak dan guru mampu berinteraksi, berdialog mendalam dan saling membuhtukan dalam proses belajar mengajar.

- Peserta didik dan guru dapat menjadi pendengar pembicara dan pemikir yang baik. Hal ini akan menjadikan proses belajar mengajar efektif dan efisien karena anak dan guru sudah mampu mengenal diri mereka sendiri siapakah mereka dalam proses belajar mengajar.

- Dapat diimplementasikan dalam kehidupan sehari-hari. Ketika makna yang telah didapatkan dalam proses belajar mengajar mereka, akan lebih mudah bagi mereka untuk melakukannya/mempraktekannya dalam lingkungan dimana mereka tinggal.
- Lebih menekankan pada nilai, sikap dan kepribadian. Ciri-ciri ini menjadi lebih baik ketika proses belajar mengajar dapat dimaknakan dengan baik oleh anak, maka yang aka dipikirkan dan dilakukan anak adalah hal-hal yang selalu mengutamakn nilai, sikap dan kepribadian mereka bagi banyak orang.

Model Deep Dialog/Critical Thingking dalam pembelajaran dikonsentrasikan dalam mendapatkan pengalaman, melalui dialog secara mendalam dan berpikir kritis, tidak saja menekankan keaktifan peserta didik pada aspek fisik akan tetapi juga aspek intelektal, sosial, mental, emosional dan spiritual.

Secara sederhana dialog adalah percakapan antara orang-orang dan melalui dialog tersebut dua masyarakat/kelompok atau lebih yang memiliki pandangan berbeda-beda bertukar ide dan pengalaman.

Deep Dialogue dapat diartikan bahwa percakapan antara orang-orang tadi harus diwujutkan dalam hubungan yang interpersonal, saling keterbukaan, jujur dan mengandalkan kebaikan.

Sedangkan Critical Thinking adalah kegiatan berpikir yang dilakukan dengan mengoperasikan potensi intelektual untuk menganalisis, membuat pertimbangan dan mengambil keputusan secara tepat dan melaksanakannya secara benar. (Al Hakim, Suparlan:2010)

Pendapat lain mengemukakan bahwa sebagai pendekatan pembelajaran pada dasarnya Deep Dialog/Critical Thinking bukanlah sebuah pendekatan yang baru sama seekali, akan tetapi telah diadaptasikan dari berbagai metode yang telah ada sebelumnya.

Oleh karena itu Deep Dialog dan Critical Thinking bisa menggunakan semua metode pembelajaran yang telah digunakan sebelumnya seperti Multiple Intelligences, Belajar Aktif, kentrampilan Proses ataupun Partheship Learning Method, sebagimana yang dikembangkan oleh Eisler. (Ellison Laura:2000) Dengan demikian, filosofi DD/CT melakukan penajaman-penajaman terhadap seluruh metode pembelajaran yang telah ada, baik yang bersifat konvensional maupun yang bersifat inovatif.

Beberapa prinsip yang dikembangkan dalam DD/CT adalah adanya komunikasi dua arah dan prinsip saling memberi yang terbaik, menjalin hubungan kesederajatan dan keberadaban serta 
Jefri Souhuwat

empatis yang tinggi, sehingga diharapkan akan meningkatkan pemahaman terhadap dirinya dan terhadap orang lain yang berbeda dari mereka, dan oleh karena itu akan memperkuat penerimaan dan toleransi terhadap perbedaan-perbedaan.

Pada pendekatan model pembelajaran ini siswa diharapkan akan senantiasa berperan aktif dalam setiap pembelajaran, menemukan dan meneruskan sendiri suatu konsep, mendefenisikan menurut kata-kata sendiri, menjadikan penguasaan konsep lebih tahan lama dan mengedap dalam pikirannya.

Dari pengertian di atas dapat dipadami bahwa dengan DD/CT seorang disamping dapat mengenali diri sendiri juga mengenal diri orang lain.

Selain itu dengan DD/CT orang akan belajar mengenal dunia lain di luar dunia dirinya dan selanjutnya mampu menghargai perbedaanperbedaan yang ada di dalam masyarakat.

Hal itu membuka kemungkinan-kemungkinan untuk memahami makna yang fundamental dari kehidupan secara individual dan kelompok dari berbagai dimensinya.

Dengan demikian pada skala yang lebih luas, dialog mendalam dan berpikir kritis lebih mengandalkan 'cara berpikir baru' (new way of thinking) untuk memahami dunia. (Swidler. L. Regilion:2000)

Deep Dialog/Critical Thinking memiliki lima komponen yakni Hening, Membangun Komunitas, Kegiatan inti dengan strategi penemuan konsep (Concept Attainment) dan Cooperatif Learning, refleksi dan evaluasi. (Swidler. L. Regilion:2000)

\subsection{Keheningan sebagai landasan penguatan jati diri baik secara internal maupun eksternal}

Hening, yang dimaksud adalah situasi tenang sebelum pelajaran, atau dapat dilakukan dengan berdoa karena hal tersebut dapat menghadirkan hati dan pikiran siswa-guru pada pembelajaran saat itu. Sebagaimana dikemukankan oleh Swidler dalam Sri Untari, dkk yang menekankan pentingnya hening dalam segala aktifitas, karena menurutnya dengan hening seseorang telah menjalin interaksi internal yakni dengan dirinya maupun ekstern yakni dengan Tuhan. Lebih lanjut dikemukakan bahwa hening membawa manusia pada pengendapan hati dan pikiran, sehingga memudahkan proses dialog mendalam. (Sri Untari:2008)

Anak dibawa dalam sebuah proses dimana pengenalan diri secara utuh, sehingga dalam keheningan itulah interaksi dirinya dengan Tuhan menjadi sebuah hal yang diutamakan untuk proses perubahan perilaku atau karakter dirinya.

\subsection{Komunitas Sebagai Relasi Yang Membangun}

Membangun komunitas adalah menciptakan keterikatan positif sebagai suatu kesatuan dengan menekankan kesamaan tujuan dan saling menghargai antara anggota. Kegiatan membangun komunitas juga merupakan sesuatu yang sangat penting bagi masyarakat majemuk. Oleh karena itu apabila dalam pembelajaran telah dibangun keterikatan dalam komunitas kecil (kelas) maka pada skala makro sikap dan perilaku toleransi, menghargai perbedaan, terbuka terhadap kritik, berani tampil beda dan sikap terpuji lainnya akan dapat mengantarkan siswa menjadi warga Negara yang demokratis.

Demokratis yang dimaksudkan adalah bahwa anak mampu menghagai keperbedaan yang ada dalam dirinya dan diri orang lain atau temannya sehingga kebiasaan saling menghargai kelompok atau komunitas menjadi bagian terpenting dalam diri seorang anak.

\subsection{Penemuan Konsep Untuk Kemandirian Diri}

Kegiatan penemuan konsep dan pembelajaran kooperatif adalah merupakan struktur mental yang digunakan untuk mengorganisasikan dan mengategorikan kenyataan. Model pembelajaran penemuan konsep sesuai untuk menanamkan suatu konsep ilmu pengetahuan anak dengan cara menemukan sendiri. (Achmad Sugandi:2004)

Kegiatan ini memperhatikan prinsip 4W dan $1 \mathrm{H}$, yaitu What, Why, When, Where dan How, sehingga merangsang daya kritis siswa dalam memahami secara menyeluruh, menangkap permasalahan, mencari solusi permasalahan dengan caranya sendiri dan bantuan orang lain, dan mengambil keputusan yang tepat dan bermanfaat bagi diri dan lingkungannya.

Daya kritis anak diuji dalam proses ini. Ketika anak boleh berinteraksi dengan Tuhan lewat keheningan, memahami jatih dirinya sebagai makluk ciptaan Tuhan, kemudian belajar menghargai perbedaan sesamanya, anak akan dituntun untuk menjadi kritis dalam proses mengelola pikiran dan tindakannya. Kemungkinan-kemungkinan berfikir dan bertindak positif akan semakin menonjol dalam diri anak tersebut, sehingga jati dirinya menjadi sebuah taruhan bagaimana hal baik dan buruk yang 
seharusnya menjadi sesuatu hal yang benar-benar ideal yang harus dilakukan dalam berbagai hal.

\subsection{Refleksi Membangun Kesadaran Diri}

Refleksi, merupakan sesuatu yang dapat dipandang sebagai keunggulan pendekatan $\mathrm{DD} / \mathrm{CT}$, kegiatan ini bukan menyimpulkan materi pelajaran tetapi sebagai sarana anak untuk memberikan pendapat tentang pembelajaran yang telah dilakukan.

Menurut Nasution siswa merupakan factor penting untuk menilai metode baru tersebut dan memberikan saran-saran yang berharga. Saling intropeksi baik guru maupun siswa, memberikan ungkapan bebas dan pandangan, usul terbaiknya demi kebaikan bersama. Refleksi memiliki fungsi mendidik pada siswa untuk menyukai belajar dari pengalaman yang telah dilaluinya. (Nasution:2011)

Anak akan lebih diasah untuk bagaimana kemampuan dirinya memahami sesuatu hal yang terjadi dalam kehidupannya, baik dari dalam dirinya sendiri maupun dalam diri orang lain. Sebuah konsep merefleksi sebagai sebuah pengalaman dirinya yang akan meuntun akan menjadi lebih baik.

\subsection{Evaluasi sebagai ukuran pemicu ketercapainnya perubahan karakter.}

Evaluasi seperti yang dikatakan Daryanto Bahwa Evaluasi merupakan alat untuk mendapatkan informasi yang akurat mengenai tingkat pencapaian tujuan instruksional oleh siswa. Sehingga guru dapat mengupayakan tidak lanjut atas pencapaian tersebut. (Daryanto:2009) Evaluasi sebagai sebuah tingkat pengambilan keputusan bagi anak ketika sudah melewati beberapa tahapan proses pembelajaran yang akan merubah dirinya dari segi pemahamannya tetapi juga tingkah lakunya.

Dengan demikian model pembelajaran Deep Dialog dan Critical Thiking menjadi sebuah landasan utama pendidik untuk mendidik anak menuju kearah yang lebih baik secara kognitif, afektif dan psikomotorik tetapi yang lebih terpenting adalah bahwa anak secara sadar memiliki perubahan karakter yang baik untuk mendukung proses kemajuan dirinya yang berakar dari dalam dirinya sendiri.

\section{METODOLOGI PENELITIAN}

Metodologi penelitian adalah suatu pengkajian dalam mempelajari segala bentuk peraturan yang terdapat dalam sebuatan penelitian. (Husaini Usman dan Purnomo Setiady:1998) Selain itu juga metode penelitian mempunyai pengertian yakni jalan ataupun cara-cara yang nantinya akan ditempuh dengan tujuan dan lebih mendalami objek studi.

Dalam sebuah metode penelitian dibutuhkan adanya sebuah pendekatan yang sangat berguna untuk menentukan objek penelitian yang akan diteliti dan sekaligus akan dapat menentukan subjek atau sumber dalam memperoleh data.(Koetjaraningrat:1997)

Penelitian ini dilakukan dengan menggunakan pendekatan penelitian kualitatif atau naturalistic.Dikatakan naturalistic karena berlangsung penelitian dalam latar yang wajar/natural sebagaimana adanya, tanpa dimanupulasi dan proses berbentuk siklus yang dimaksudkan adalah tahap pertama adalah tahap orientasi, pada tahap ini penelitian berusaha untuk meneliti tentang adanya Jemaat. Tahap kedua merupakan tahap eksplorasi, yang mana peneliti berusaha untuk mendapatkan informasi berdasarkan wawancara observasi. Dalam tahap ini peneliti berusaha untuk mendapatkan informasi yang lebih mendalam dari informan yang berkompoten atau para pengasuh yang terlibat langsung dalam proses pembelajaran. Tahap ketiga adalah tahapan penyesuaian tentang kebenaran data. Tahapan ini adalah tahapan akhir dimana hasil pengamatan dan wawancara yang telah dianalisis akan diberikan kepada informan untuk mencari tahu kebenaran laporan peneliti. (Koetjaraningrat:1997)

Penelitian ini berlokasi pada Jemaat GPM Soya dengan jumlah sector pelayanan 9 sektor, Lokasi ini dipilih karena muatan penelitiannya semua di arahkan ke semua Pengasuh Jemaat GPM Soya. Sasaran penelitian ini yaitu Pengasuh dan Anak Jemaat GPM Soya serta Informan dalam penelitian ini adalah Pengasuh dan tokoh-tokoh Gereja

\subsection{Teknik pengumpulan data}

Observasi atau pengamatan langsung ke lapangan atau lokasi penelitian dengan maksud untuk memperoleh data atau karakteristik masyarakat di lokasi penelitian dan karakteristik masalah itu sendiri. Wawancara langsung dengan informan sebagai upaya untuk mendapatkan sejumlah data yang berhubungan dengan masalah penelitian serta kepustakaan dan berbagai buku- 
Jefri Souhuwat

buku dokumen lainnya. Pustakaan ini, bermanfaat menyusun landasan teoritis yang akan menjadi tolak ukur untuk menganalisis hasil interpretasi data penelitian lapangan guna menjawab persoalan pada rumusan dan tujuan masalah yang diteliti.

\subsection{Teknik Analisa Data}

Reduksi Data adalah data yang diperoleh di lapangan/diketik dalam bentuk uraian atau laporan yang terinci.Laporan-laporan itu perlu direduksi, dirangkum, dipilih hal-hal yang pokok, difokuskan pada hal-hal yang penting dicari tema atau polanya. (Koetjaraningrat:1997)

Display Data Agar dapat melihat gambaran keseluruhan atau bagian-bagian tertentu untuk mengambil kesimpulan yang benar, harus dusahakan membuat berbagai pencatatan agar dapat menguasai data dan tidak tenggelam dalam tumpukan detail. Membuat display juga merupakan bagian dan analisis. (Koetjaraningrat:1997) Kesimpulan senantiasa harus diverifikasi selama penelitian maupun proses analisis data berlangsung. (Koetjaraningrat:1997)

\section{Ucapan Terima Kasih}

Pada kesempatan ini, terimakasih saya ucapkan kepada redaktur yang telah memberikan masukan yang berharga sehingga tulisan ini dapat disajikan di jurnal Institutio. Terimakasih juga saya ucapkan kepada seluruh dewan redaksi jurnal Institutio yang sudah memberikan ruang diskusi. Semoga bantuan dan dukungannya mendapatkan balasan yang sebanyak-banyaknya dari Tuhan kita Yesus Kristus, Amin.

\section{Pustaka Acuan}

Achmad Sugandi, Teori Pembelajaran. Semarang : UPT MKK UNNES, 2004.

Al Hakim, Suparlan, Strategi Pembelajaran berdasarkan Deep Dialog/Critical Thinking. Jakarta : Ditjen Dikdasmen, 2010.

Arhana, Ketut. 2007. Model Pembelajaran Inofatif Berbasis Deep Diaologue/Critical Thinking.[ Online]. Tersedia: http://fip.unesa.ac.id/bank/jurnal/tp-101-3 Model

Pembelajaran Inovatif Berbasis Deep Dia logue Critical Thinking.pdf

Daryanto, Panduan Proses Pembelajaran Kreatif dan Inovatif. Jakarta : AV.Publisher,2009.

Ellison Laura, Tujuh Langkah Deep Dialogue/Dialog Mendalam yang diterapkan
Pada Para Guru : "Pendidikan Anak Seutuhnya". Unicef, 2000.

Haidar Bagir, "Belajar dari Pengalaman Finlandia" sebuah Pengantar dalam Pasi Sahlberg, Finnish Lessons: Mengajar Lebih Sedikit, Belajar Lebih Banyak ala Finlandia, terj. Ahmad Mukhlis. Jakarta: Kaifa Learning. 2014

Hamdani, Strategi Belajar Mengajar. Pustaka Setia, Bandung. 201.

Husaini Usman dan Purnomo Setiady . A. Metodologi Penelitian Sosial. PT Bumi Aksara, 1998.

Istighfatur Rahmaniyah, Pendidikan Ptika, malang:UIN Maliki Press,2010.

Koetjaraningrat, Metode-metode Penelitian Masyarakat. Jakarta : PT Gramedia Pustaka Utama, 1997.

Kementrian pendidikan Nasional Paduan Pelaksanaan Pendidikan Karakter. Jakarta : Badan Penelitian dan Pengembangan Pusat Kurikulum dan Perbukuan, 2011.

Nasution, Berbagai Pendekatan dalam Proses Belajar Mengajar. Jakarta : PT.Bumi Aksara, 2011).

Pusat Pembinaan dan Kebudayaan, Kamus Lengkap Bahasa Indonesia Edisi Kedua. Jakarta: Balai Pustaka, 1995.

Sri Untari, Suparland Al Hakim, Ktut Diara Astawa dan Nur Wahyu Rochmadi, “ Pengembangan Bahan Ajar dengan Model Deep Dialog/Critical Thinking untuk meningkatkan kemampuan berdialog dan berpikir kritis Siswa SMA di Jawa Timur, (Jurnal Penelitian Pendidikan Vol 18 Nomor 1 Tahun 2008), hal 154-177.

Sumaryono. Pengembangan Perangkat Pembelajaran Matematika Realistik untuk Melatihkan Kemampuan Berpikir Kritis. Skripsi IAIN Sunan Ampel Surabaya : Tidak dipublikasikan, 2010.

Suyatno, Menjelajah Pembelajaran Inovatif, Masmedia, Buana Pustaka, Sidoarjo, 2009.

Swidler. L. Regilion Dialogue in Dialogue era. Philadelpia : University Press, 2000.

Trianto, M. Pd. Mendesain Model Pembelajaran Inovatif-Progresif : Konsep, Landasan, dan Implementasinya pada Kurikulum Tingkat Satuan Pendidikan (KTSP), Jakarta: Kharisma Putra Utama, 2009.

Zulmaulida, Rahmy. Pengaruh Pembelajaran dengan Pendekatan Proses Berpikir Reflektif Terhadap Peningkatan 
Kemampuan Koneksi dan Berpikir Kritis

(Deep Dialog dan Critical Thiking Sebagai Model Penerapan Pendidikan Karakter)

Matematis Siswa. Skripsi Universitas

Pendidikan Indonesia :Tidak

dipublikasikan, 2012. 